\title{
Også hjelpere trenger \\ hjelp
}

I krisesituasjoner stiller hjelperne i det psykososiale hjelpeteamet opp. Etterpå et det viktig at noen også stiller opp for dem.

\section{Forfattere}

\section{Cecilia Lindsten}

Vernepleier

Rus- og psykiatritjenesten, Narvik kommune

\section{Marianne Torjussen}

Sykepleier

\section{Nøkkelord}

\begin{tabular}{|l|l|l|l|}
\hline Psykososialt hjelpeteam & Krise Katastrofe debriefing
\end{tabular}

Sykepleien 2017 105(1)(70-73)

DOI: https://doi.org/10.4220/Sykepleiens.2017.59819

\section{HOVEDBUDSKAP}

En hjelper i et psykososialt kriseteam møter mange ulike mennesker med mange forskjellige erfaringer fra hendelser de har opplevd. Det er viktig å ta vare på hver enkelt hjelper, slik at hjelperen kan ivareta seg selv. 
Det er endelig middag, ungene krangler litt mens de setter seg til bords. Det smeller i ytterdøren, og jeg hører mannen min sukke over rotet i gangen og søppelposen alle har trødd over. Telefonen ringer - jeg ser i displayet at det er sjefen min. Jeg kjenner pulsen stige. Lederen min ringer ikke om det ikke har skjedd noe alvorlig. Jeg går litt unna kaoset på kjøkkenet og svarer. Sjefen sier det har vært en ulykke rett sør for byen. Rådmannen har bestemt seg for å samle det psykososiale kriseteamet, og hun spør om jeg kan møte på jobb og hvor lang tid jeg trenger for å være der. Jeg ser på mannen min som står litt undrende og følger med på samtalen, og han sier «Bare gå, du, jeg passer på det her», og ser inn på kjøkkenet.

\section{三 «Kroppens signaler forteller meg at jeg er i beredtmodus.»}

Jeg kjenner pulsen slå raskere i kroppen, og musklene spenner seg. Jeg merker at kroppens signaler forteller meg at jeg er i «beredtmodus». Middagen og rotet er glemt, og hodet er plutselig koplet på igjen. Jeg stopper litt opp for å reflektere over situasjonen og tenker på hva jeg trenger å ha med meg. Jeg tar med meg telefon, lader og nok klær til å kunne være i beredskap over tid. Jeg kler på meg, og ett kvarter senere er jeg på jobb. De andre i teamet er også kommet. Spenningen og alvoret er til å ta og føle på i rommet. Vi har gjort dette i flere år nå; vi har møtt forskjellige mennesker som har opplevd ulike hendelser og traumatiske opplevelser.

\section{Hjelpere i kriseteam}

Rådmannen har vurdert at ulykken sør for byen er av et slikt omfang at kommunens psykososiale kriseteam skal samles. Hvert enkelt medlem av teamet gjør seg klar til å møte ulykken og eventuelle skadete, rammete og pårørende. 
Hjelperen bruker hele seg i møte med mennesker som kan ha opplevd noe veldig vanskelig, og som potensielt kan ha opplevd noe traumatisk. Hjelperen gjør seg klar mentalt: hode og kropp er innstilt på å yte, noe som også kan gjøre hjelperen sårbar. Hjelperen må kjenne på sitt eget spenningsnivå for å kunne gi god hjelp og samtidig ivareta seg selv.

Alle kommuner i Norge har et overordnet ansvar for å ivareta kommunens befolkning med psykososial oppfølging ved kriser, ulykker og katastrofer. Veilederen for psykososiale tiltak ved kriser, ulykker og katastrofer er tydelig på at det kan være behov for å iverksette psykososiale tiltak som en del av kommunens øvrige helsemessige og sosiale beredskap (1).

Målsettingen for det psykososiale oppfølgingsarbeidet er nødvendig støtte og hjelp for å håndtere krisesituasjoner av potensielt traumatiserende karakter. Hjelpen skal fremme mestring i en akutt fase, opprettholde sosial fungering samt dempe symptomer og reaksjoner. Det skal medvirke til at normale reaksjoner settes i gang. Målet er å forebygge fremtidige helseproblemer og/eller sosiale problemer samt bidra til en god livskvalitet (2).

\section{Krav til hjelperen}

Dyregrov er kjent for sine prinsipper for god kriseintervensjon. Han er tydelig på at vi som hjelpere må gi hensiktsmessig oppfølging, og han mener etterlatte trenger følgende:

- rask og tidlig hjelp

- proaktiv hjelp, at hjelperen spør

- stabilitet og kontinuitet

- kompetanse og kvalitet

- fleksibilitet og individuelt tilpasset hjelp

- hjelp som varer over tid

- likemannsstøtte må sikres hvis det er ønskelig 
Dyregrovs prinsipper sier noe om hva hjelperen må gjøre seg klar til. Prinsippene forteller også at det stilles klare krav til hjelperen siden vedkommende må gi tidlig respons og utvise personlig og faglig kompetanse. Krisehåndtering handler om å gi en opplevelse av trygghet og tilstedeværelse, og om å bidra med varme pledd, mat og drikke.

Det er nærliggende å tenke at det ikke bare er de etterlatte som har behov for en slik oppfølging i ettertid - alle trenger en form for oppfølging etter sterke hendelser, både under selve hendelsen og en tid etter. Også hjelperne trenger slik oppfølging (3).

Debrifing inngår som en del av en total oppfølging av de psykososiale kriseteamene. Men vi hjelpere er ulike, og behovet for oppfølging i ettertid vil nok variere fra person til person og fra hendelse til hendelse.

\section{三 «Alle kan få en sterk krisereaksjon hvis omstendighetene er vanskelige nok.»}

Som hjelper bruker vi vår innlevelsesevne i møte med mennesker. Vi opplever det som meningsfylt, og derfor har mange av oss valgt å jobbe i helsesektoren. Vi blir invitert inn i livet til andre på godt og vondt. Vi kommer nær mennesker som har det vanskelig, og som i fortellingen over, mennesker med en potensielt traumatisk opplevelse. Dette utgjør også en risiko for den som er i hjelperrollen. Når kroppen aktiveres, aktiveres også stress. 
Stress er ikke bare negativt; det finnes positivt stress som gjør at man føler seg opplagt og engasjert. Det positive stresset er knyttet til mestring og gjør at man har kontroll over situasjonen (4). Hvor aktivisert og stresset vi er som hjelper, påvirker nok hvordan vi håndterer situasjonen i ettertid. Når kroppen, pusten og musklene gjør seg klar, er ikke alltid hodet helt med. Vi kan fort kjenne på stress. Da er det lett å bli distrahert og glemme hva som er viktig.

\section{Tent, men ikke spent}

I henhold til modellen til Lillevik og Bufetat øst er vi «tent, men ikke spent» (figur 1). Hjelperen er fokusert på oppgaven som skal utføres. Ut fra modellen befinner hjelperen seg på hele den øvre buen, fra interessert til konsentrert. Negativt stress er knyttet til opplevelsen av å miste kontroll. Hjelperen kan nok føle at situasjonen er uoversiktlig og kanskje skremmende.

I fortellingen over sier lederen i telefonen at det har vært en ulykke. Hun er kortfattet i telefonen og gir lite informasjon. Hjelperens hode aktiveres uten en tydelig oversikt over hendelsen. Hjelperen gjør seg klar til å møte hendelsen, som har et uvisst omfang. Hjernen til hjelperen jobber og responderer etter hvert på det hjelperen sanser og opplever i sitt virke.

Figur 1. Optimalt spenningsnivå

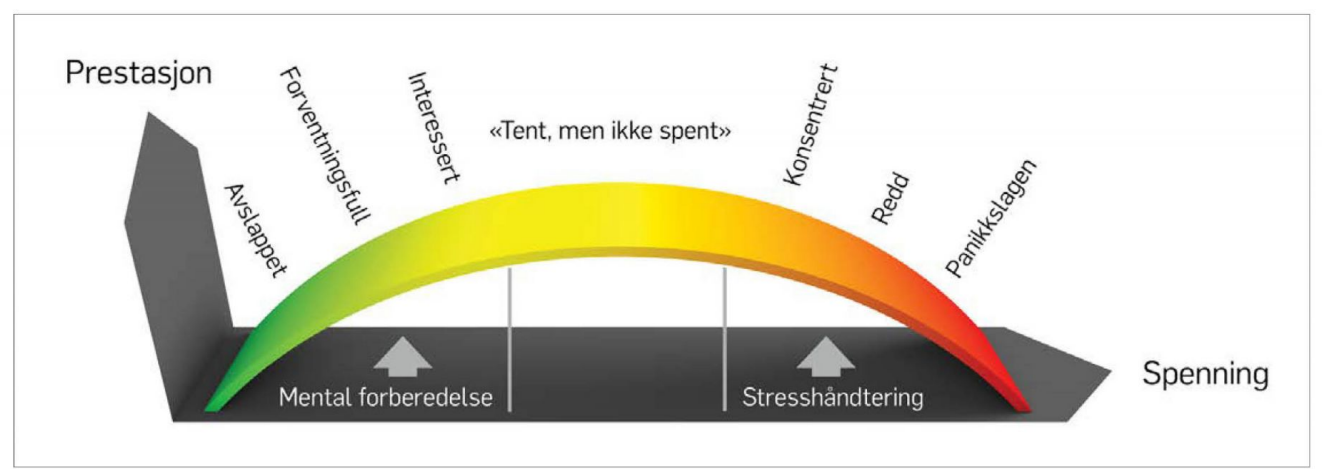

OPTIMALT SPENNINGSNIVÅ: Modellen beskriver hjelperens optimale spenningsnivå. Nivået går fra å være avslappet, forventningsfullt og interessert til det optimale på toppen, der man er «tent, men ikke spent». Modellen viser også overgangen til rødt, der hjelperen opplever negativt stress. Lillevik O, Bufetat øst (9). Gjengitt med tillatelse. 
Alle kan få en sterk krisereaksjon hvis omstendighetene er vanskelige nok. Også hjelperen er sårbar ved tøffe hendelser. Hjelperen gjør seg klar til å ta imot lidelse, tap, sorg og fortvilelse.

Hjelperen vet ikke på forhånd hvordan den enkeltes fortelling er. De lytter, formidler ro, gir omsorg - er der med hode og kropp. Samtidig vet vi at traumene fester seg i sanseapparatet, også hos hjelperne.

Potensielt traumatiserende hendelser kjennetegnes ved at de truer livet og helsen til oss selv eller våre nærmeste. De kan, men behøver ikke, resultere i akutte og langsiktige konsekvenser for den eller dem som rammes (5). En krisereaksjons karakter avhenger av hvor den inntreffer, og hvor lenge den varer. Det kommer an på hvor godt den enkelte er forberedt på krisereaksjonen.

Det er viktig å fokusere på virkningen etter en sterk reaksjon, også hos hjelperen. For å være til god hjelp for den rammete må hjelperen være mentalt til stede i den oppgaven han eller hun er satt til å utføre. I denne sammenhengen forstår og tolker vi modellen til Lillevik og Bufetat øst som at hjelperens mentale forberedelse er viktig. Vi som hjelpere har en faglig bakgrunn, men det er kanskje like viktig med erfaring, egnet personlighet, evne til å håndtere stress samt opplevelse av kontroll og av at arbeidet vi gjør, gir mening.

\section{Folk er ulike}

En hjelper i et psykososialt kriseteam møter mange ulike mennesker med like mange erfaringer fra hendelsen de har opplevd. Når en ulykke inntreffer, har de involverte erfart selve ulykken forskjellig, fra hvert sitt ståsted. De har sett, hørt, luktet og kjent helt ulike ting.

Hvert enkelt menneske har også med seg sin egen livserfaring inn i den nye erfaringen, og erfarer dermed potensielt traumatiserende hendelser ulikt (6). 
I vanskelige situasjoner benytter mennesket automatisk forskjellige psykiske beskyttelsesmetoder. For oss som jobber som hjelper, handler det om å identifisere dem som ikke klarer å håndtere psyken på egen hånd og står i fare for å utvikle posttraumatisk stresslidelse (PTSD). I møte med den rammete går jobben vår da ut på å holde ro og oversikt i situasjonen. Det handler også om å gi håp.

Hendelser som inntreffer plutselig og uventet, og som påvirker en person over en lengre tidsperiode, er vanskeligere å håndtere både for utrente hjelpere og for profesjonelt mannskap. Som hjelper skal jeg ikke gå inn i et ulykkesområde uten å ivareta min egen sikkerhet. Dette lærer vi i førstehjelp, og det er like viktig å kjenne på sin egen sårbarhet når man møter mennesker med en potensielt traumatisk opplevelse.

Vår erfaring med arbeidet i det psykososiale kriseteamet kan i starten oppleves som uoversiktlig. Vi vet ikke hvor mange som er rammet, og om de skal på et pårørendesenter, eller i hjem. Beskjeden fra lederen sier ikke noe om hvor mange som er involvert $\mathrm{i}$ ulykken eller hvor mange som har vært vitne til hendelsen. Jeg vet heller ikke omfanget av eventuelle etterlatte og pårørende.

\section{Beskytte seg selv}

I hverdagsspråket er «krise» et ord vi bruker når vi mister oversikten. Dyregrov bruker begrepet når det dreier seg om noen få personer. Om det er mange mennesker involvert, bruker han «katastrofe». Innenfor medisin brukes katastrofe når antall skadde overstiger den lokale behandlingskapasiteten (3). Som hjelper skal jeg gjøre meg klar til å møte alt fra krise til katastrofe. Jeg må kjenne på mitt eget spenningsnivå for å beskytte meg selv i hjelperrollen. 
Som regel er det potensielt traumatiske hendelser den rammete trenger hjelp til, men det er viktig å se en krise i sammenheng med situasjonen. Det kan være mange mennesker til stede, og situasjonen kan oppleves som uoversiktlig også for hjelperen. Det er en del faktorer som spiller inn i en slik situasjon. En rekke av disse faktorene gir høyere eller lavere risiko for å utvikle PTSD, både hos hjelperen og hos den som trenger behandling. Personlighetstrekk som optimisme, fremtidsrettethet, høyere selvtillit og «hardhet» ser ut til å beskytte mennesket. Det viser seg at intelligens, evne til fleksibel tilpassing og evne til å fremme egne interesser fører til færre reaksjoner (7).

\section{三 «Traumene fester seg i sanseapparatet, også hos hjelperne.»}

Modellen over beskriver et optimalt spenningsnivå.

Nivået går fra å være avslappet, forventningsfull og interessert til det optimale på toppen, der man er «spent, men ikke tent». Modellen viser også overgangen til rødt, der nivået går fra konsentrert og redd til det blodrøde feltet panikkslagen. Spenninger i kroppen kjennes på pusten, vi kjenner dem på pulsen i brystet, og kroppen blir spent. For meg som hjelper er det viktig å fokusere på hvordan den rammete sanser situasjonen.

Det er svært viktig å være en god lytter. Det handler om å være i stand til å hjelpe mennesker og samtidig kunne mestre situasjonen selv. Hjelperen må stå sammen med den enkelte når situasjonen er vanskelig og uoversiktlig. Når arbeidet er i gang, må hjelperne og ledelsen også følge med på dem som er satt til å hjelpe. Som hjelpere må vi følge med på hverandre og kjenne på egne begrensninger. Modellen kan brukes som et hjelpemiddel i det psykososiale arbeidet, både for hjelperne og dem som er rammet.

\section{Kjenn spenningsnivået}


Vår kunnskap om livet er en av nøklene til et godt psykososialt arbeid. Denne kunnskapen handler om å se sammenhengen mellom menneskesyn, kunnskap, kultur, hjelp og behandling. Kunnskap utvikles sammen med andre i situasjonen. Man kan ikke jobbe uten å reflektere over sitt «jeg» og sitt bidrag i arbeidet med mennesker i en potensielt traumatisk opplevelse, eller med mennesker som føler avmakt. Man må ta kontroll over seg selv og være oppmerksom på hvilke signaler man sender ut (8).

Modellen som vi presenterte over, kan brukes som et hjelpemiddel for hjelperne i de psykososiale kriseteamene til å kjenne på hvilket spenningsnivå vi er på. I arbeid med andre mennesker med en potensielt traumatisk opplevelse må vi hjelpere være oppmerksomme på hva hjelpen gjør med oss som hjelpere. Vi har erfart at det skjer noe med vårt eget spenningsnivå når vi blir kalt ut i det psykososiale arbeidet. Det er viktig å være bevisst på sitt eget spenningsnivå i møte med den rammete.

Det å være hjelper over tid i en situasjon som er uoversiktlig, alvorlig, som innebærer skader og kanskje brå død, preger oss. Hjelpere blir berørt og kan bli påvirket i ettertid. Vi må ivareta oss selv og ta vare på hverandre. Kanskje arbeidsplassen kan legge til rette slik at de som har vært på oppdrag, kan være på jobb neste dag. Hvis man får mindre krevende oppgaver, kan man også få tid til å prate med kollegaer og komme tilbake til hverdagen på det mentale planet.

Mange har rutiner på oppfølging av det psykososiale kriseteamet, og disse rutinene er beskrevet $i$ en veileder som Helsedirektoratet har gitt ut (1). Det er viktig å ta vare på hver enkelt hjelper, slik at hjelperen skal kunne ivareta seg selv.

\section{Referanser}


1. Helsedirektoratet. Veileder for psykososiale tiltak ved kriser, ulykker og katastrofer. Oslo:

Helsedirektoratet, 2011. IS-1810. Tilgjengelig fra:

https://helsedirektoratet.no/Lists/Publikasjoner/Attachments/253/Veileder-

for-psykososiale-tiltak-ved-kriser-ulykker-ogkatastrofer-IS-1810.pdf (Nedlastet 14.12.2016).

2. Næshe I. Psykososial beredskap, reaksjoner og oppfølging etter brå død. Forelesning ved UIT campus Narvik 25.11.2015.

3. Dyregrov K, Dyregrov A. Sosial nettverksstøtte ved brå død: Bergen: Fagboksforlaget, 2007.

4. Helsekompetansesenteret. «Stø

kurs». Tilgjengelig fra:

http://kurs.helsekompetanse.no/traumebehandling/heia

(Nedlastet 14.12.2016).

5. Myrvang A. Krisehåndtering: Forelesning ved UIT campus, Narvik 17.03.2016.

6. Råkil M. Om sekundærtraumatisering, belastningsreaksjoner og selvivaretakelse. Forelesning ved UIT campus, NARVIK 24.05.2016.

7. Helsedirektoratet. Mestring, samhørighet og håp. Veileder for psykososiale tiltak ved kriser, ulykker og katastrofer. Oslo: Helsedirektoratet, 2016. IS-2428.

Tilgjengelig fra:

https://helsedirektoratet.no/Lists/Publikasjoner/Attachments/1166/Mestring,samhorighet-og-hap-veileder-for-psykososiale-tiltakved-kriser-ulykker-og-katastrofer-IS-2428.pdf (Nedlastet 14.12.2016).

8. Skærbæk E, Nilsen M. Psykososialt arbeid, fortellinger, medvirkning og fellesskap. Oslo: Gyldendal Akademisk. 2014.

9. Lillevik O, Bufetat øst. Modell 1. Optimal spenningsnivå. 